\title{
COUNSELING AND GUIDANCE PROGRAMS FOR WOMEN WITHIN THE CONTEXT OF PARADIGM SHIFT IN US PRISON SERVICES
}

\author{
Hatice KOÇ KANCA*
}

\section{Makale Bilgisi}

Makale Türü: Araştırma Makalesi, Geliş Tarihi: 10 Haziran 2020, Kabul Tarihi: 29 Temmuz 2020, Yayın Tarihi: 30 Eylül 2020, Atıf: Koç Kanca, Hatice. "ABD Cezaevi Hizmetlerinde Paradigma Değişimi Bağlamında Kadınlar İçin Danışmanlık ve Rehberlik Programları". Dinbilimleri Akademik Araştırma Dergisi 20/2 (Eylül 2020): 841-869.

https://doi.org/10.33415/daad.750875

Article Information

Article Types: Research Article, Received: 10 June 2020, Accepted: 29 July 2020, Published: 30 September 2020, Cite as: İyibilgin, Orhan. "Counseling And Guidance Programs For Women Within The Context Of Paradigm Shift In Us Prison Services". Journal of Academic Research in Religious Sciences 20/2 (September 2020): 841-869.

https://doi.org/10.33415/daad.750875

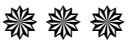

\section{Abstract}

The American criminal and correctional authorities have designed and implemented programs aiming rehabilitation of male prisoners alone, for many years, neglecting women prisoners and the correctional works for their problems. ${ }^{1}$ However, due to the increasing number of female prisoners in United States prisons, the state and federal correctional authorities have faced the fact that they focus on women-oriented problems and their solution. ${ }^{2}$ The awareness that

Dr., Georgetown University, Department of Theology, Visiting Scholar, hk766@georgetown.edu, Orcid Id: https://orcid.org/0000-0002-8322-6667

1 Stephanie S. Covington, "Women in Prison Approaches in the Treatment of Our Most Invisible Population", Women and Therapy Journal 21/1 (1998) : 141.

2 Kimberly Houser - Steven Belenko, "Disciplinary Response to Misconduct Among Female Prison Inmates with Mental Illness, Substance Use Disorders, and CoOccurring Disorders", Psychiatric Rehabilitation Journal 38/1 (2015): 24 ; Alma Harris, Building Upon The Razor Wire Women's Program By Incorporating Experiential 
has emerged over time has opened the door to the paradigm shift of American correctional authorities towards women. This awareness has led to the initiation of family protection programs in some states to address the needs of women prisoners and their families more respectfully. Moreover, it has led to the launch of several new programs: inmate mothers should be included in educational programs in order to respond to the physical, emotional and psychological needs of their children; those mothers should meet with their minor children and adolescents with games and various activities in special and child-friendly rooms outside the normal visiting room; it should be given additional visitation rights for those mothers who participate in parenting trainings; a new mother should be allowed to live with her infant in a private section for up to 18 months. ${ }^{3}$ In this article, parallel to this paradigm shift especially in the late 90s and early 2000s, some national and local correctional works and projects focused on the needs of female prisoners that was initially neglected but then taken into consideration due to the increasing number of women convicts and needs peculiar to them, will be examined. The treatments, medical processes, physical and mental treatment methods required by the clinical psychology offered to the prisoners based on prisoners' needs are out of our scope. This study, rather, focuses on practices -their effects and efficiency- carried on successfully with combined efforts of criminal correctional authorities, psychologists, municipal and church officials, social service experts and volunteers that aim to support female prisoners, especially those with children.

Keywords: Incarcerated women, Parenting preservation program, Extended prison visitation, Correctional programs.

\section{ABD Cezaevi Hizmetlerinde Paradigma Değişimi Bağlamında Kadınlar İçin Danışmanlık ve Rehberlik Programları}

Öz

Amerika ceza ve ıslah makamları uzun yıllar kadın mahkumları ve onların sorunlarına yönelik ıslah çalışmalarını ihmal ederek, yalnızca erkek mahkumları ıslaha yönelik programlar tasarlamış ve uygulamıştır. Ancak Birleşik devletler hapishanelerinde kadın mahkum nüfusunun her geçen gün artması sebebiyle, eyalet ve federal ıslah makamları kadın odaklı sorunlara eğilme ve bu çerçevede çözüm üretme gerçeği ile karşı karşıya kalmıştır. Bu konuda zaman içinde ortaya çıkan farkındalık, Amerikan ıslah makamlarının kadınlara yönelik paradigma değişikliğine kapı aralamış ve bazı eyaletlerde kadın mahkumların ve ailelerinin ihtiyaçlarının daha saygın bir şekilde karşılanması, aile koruma programlarının başlatılmasını sağlamıştır. Bunun yanında annelerin çocuklarının fiziksel, duygusal ve psikolojik ihtiyaçlarına yanıt verebilmesi için eğitim programlarına alınması mahkum annelerin çocuk ve ergen yaşta olan çocukları ile normal ziyaret odasının dışında özel ve çocuk dostu odalarda oyunlar ve çeşitli etkinliklerle bir araya gelmesi, çocuğu olan mahkum annelere ebeveynlik eğitimlerine katılması halinde ilave ziyaret haklarının tanınması, bebek sahibi olan mahkumun 18 aya kadar özel bir bölümde bebeği ile birlikte yaşayabilmesine imkan sağlayan pek çok yeni

Therapy Interventions To Treat Addictions In Women In Prison ( Ann Arbor : ProQuest LLC, 2016), 20.

3 Jeralyn Faris - Joann Miller, "Family Matters: Perceptions of Fairness Among Incarcerated Women," Prison Journal 90/ 2 ( June 2010):140. 
programın başlatılmasını da sağlamıştır. Bu makalede özellikle 90'ların sonu ve 2000'lerin başında söz konusu paradigma değişikliği paralelinde başlangıçta ihmal edilen ama artan rakamlar ve ihtiyaçlar sebebi ile dikkate alınan kadın mahkumların ihtiyaçlarına özel olarak uygulanan bazı ulusal ve yerel ıslah çalışmaları ve projeler incelenmeye çalışılacaktır. Mahkumlara ihtiyaç durumuna göre sunulan klinik psikolojinin gerektirdiği tedaviler, tıbbi süreçler ile fiziksel ve mental tedavi yöntemleri kapsam alanımız dışındadır. Bu çalışmada daha çok ceza ıslah makamları, psikologlar, belediye ve kilise görevlileri, sosyal hizmet uzmanları ve gönüllülerin birlikte yürüttüğü kadın mahkumları özellikle de anne olan mahkumları destekleme amaçlı yapılan ve başarı sağlamış uygulamalara ve bu uygulamaların etkisi ve verimliliğine değinilecektir.

Anahtar Kelimeler: Mahkum kadınlar, Aile koruma programları, Artırılmış hapishane ziyaretleri, Islah programları.

\section{Introduction}

The State and Federal Correctional Authorities of the United States have directed all their attention and caution to male prisoners in the past, and neglected efforts to understand or solve the problems of female prisoners. ${ }^{4}$ However, until the early 80 s, the female prisoners' population constituted a very small percentage of the general prisoner population, therefore, it is possible to say that in those years female prisoners were described as "forgotten population" with very good intentions ${ }^{5}$ and that this situation was tolerated, at least did not cause a mass social problem. ${ }^{6}$ In fact, most of the States did not even have prisons for women in these years . In the early 80 s, there were only 12,000 female prisoners nationwide, while the rate of women's imprisonment in the last 40 years exceeded that of male prisoners ${ }^{7}$, and the lack of equality between male prisoners and female prisoners ${ }^{8}$ provided the groundwork for

4 Faris -Miller, "Perceptions of Fairness Among Incarcerated Women", 140.

5 Barbara Bloom et al., Gender-Responsive Strategies: Research, Practice, and Guiding Principles For Women Offenders ( Washington, DC: National Institute of Corrections, 2003), 3.

6 Mary E. Keaveny - Jaclene A. Zauszniewski, "Life Events And Psychological WellBeing In Women Sentenced To Prison", Issues in Mental Health Nursing 20/1 (1999): 74; Ann Booker Loper, "Adjustment of Prison of Women Convicted of Possession, Trafficking, and Nondrug Offenses", The Journal of Drug Issues 32 (2002): 25.

7 Joycelyn M. Pollock-Byrne et al., "Women, Prison, and Crime", The Journal of Criminal Law and Criminology 82/ 4 (1992): 1190.

8 Joanne Belknap, The Invisible Woman: Gender Crime, and Justice, Third Printing ( Belmont, CA: Wadsworth, 2001), 224-227; Bloom et al., Gender Responsive Strategies, 4; Merry Morash et al., "A Comparison of Programming For Women And Men in U.S. Prisons Since The 1980s," Crime \& Delinquency 40 (1994): 197. 
the criminal and correctional authorities to raise awareness of female prisoners. In this context, firstly, studies about gender differences, and the tendencies and behaviors stemming from these differences have been taken into consideration, and then maledominated correctional implementations have initially turned into activities involving all prisoners without gender separation. Thus, in the early 90s, some of the correctional boot camps accepted female prisoners ${ }^{9}$, and subsequently, only studies that prioritize women were put into effect, taking into account the women's income status, criminal profiles, physical and psychological trauma experiences, and the additional problems arising from being a mother. A more inclusive correctional paradigm has been developed that aims for a general improvement and correctional effort by including female prisoners' families and children outside.

\section{Prisoner Numbers and Proportions}

According to the official record of Bureau of Justice Statistics, as of the end of December 31,2016, there were a total of $1,506,757$ prisoners under the jurisdiction of the US state and federal correctional authorities. Of this number, 1,395,141 were male and 111,616 were female prisoners, and this figures demonstrate that $7.4 \%$ of the total prisoner population consists of female prisoners. $^{10}$

By the end of 2016, state prisons had 12,600 fewer prisoners compared to 2015 , and federal prisons had 7,300, therefore $4 \%$ fewer prisoners. The number of convicted prisoners has reached its lowest level in 2016, with the exception of those who have not been sentenced to imprisonment by the court or who have been convicted for a year or less. According to these data, even in 2016, which has the lowest number of prisoners, it is officially determined that 450 out of every 100,000 people living in the USA were convicted without any disparity in age, and considering the age of 18 and over, 582 out of every 100,000 18 years of age living in America were imprisoned. When we look at the figures in terms of women, it is seen that 33 out of every 100.000 people living in America

9 Dale G. Parent, “Correctional Boot Camps: Lessons From a Decade of Research" (National Institute of Justice, 2003), 2, http://www.ojp.usdoj.gov/nij .

10 Jennifer Bronson - E. Ann Carson, "Prisoners in 2007" (Bureau of Justice Statistics, 2019),6,http://www.bjs.gov, NCJ 252156. 
are female prisoners and 68 out of every 100.000 women are female prisoners. ${ }^{11}$ In addition, the studies of the International Center for Prison Studies have revealed that America has the largest population in terms of the number of criminals and that the number of women has the fastest increase rate among these large criminal masses. ${ }^{12}$

\section{Conditions of the Local Prisons}

The jails run by about 3000 county or municipality-run detention facilities have prisoners who have not yet been convicted of a crime. Over the last 40 years, the number of people imprisoned in local jails in the United States has increased almost fivefold. In these places, where 157,000 people were held in $1970,745,000$ people were held in 2014, and according to the figures published in 2018741,000 people were kept as of the end of $2017 .{ }^{13}$ The main objective of local jails is to prevent the risk of pre-trial escape and to avoid these people from becoming a danger to society. However, due to the inability to pay the bail and the circulation of more than 11 million prisoners per year, local jails became important problem areas in terms of the number of prisoners. ${ }^{14}$

Since 1979, the number of women imprisoned in local jails has increased 14 times across the nation, and almost half of these women have been sentenced to live behind bars. ${ }^{15}$ In addition, $60 \%$ of women in jail have not yet been convicted of a crime but had to

11 United States Census Bureau. Access: 13 October 2019, http://www.census.gov; Wendy Sawyer -Peter Wagner, "Mass Incarceration: The Whole Pie 2019". Prison Policy Initiative. $\quad 13 \quad$ Access: 2019. https://www.prisonpolicy.org/reports/pie2019.html.

12 Barbara L. Zust, "Partner Violence, Depression, and Recidivism: The Case of Incarcerated Women and Why We Need Programs Designed for Them", Issues in Mental Health Nursing 30/4 (2009) : 247-48; Harris, Building Upon The Razor Wire Women's Program, 10-15.

13 Elizabeth Swavola et al., "Overlooked: Women and Jails in an Era of Reform" (Vera Institute of Justice, 2016), 6, https://www.vera.org/downloads/publications/overlooked-women-and-jails-reportupdated.pdf.

14 Todd D. Minton - Zhen Zeng, "Jail Inmates in 2015 " (Bureau of Justice Statistics), access: 13 October 2018, 15, http://www.bjs.gov, NCJ 250394 ; Tom Dart, "To End Mass Incarceration, Think Local" (The Wall Street Journal, 2016) http://www.wsj.com/articles/ to-end-mass- incarceration-think-local- 14646427.

15 Elizabeth Swavola et al., "Overlooked: Women and Jails in an Era of Reform" , 6-7; Ann Carson, "Prisoners in 2014" (Bureau of Justice Statistics), access: 13 October 2018, 5,http://www.bjs.gov NCJ 248955. 
wait behind bars for the beginning of their trial. ${ }^{16}$ As a result, the possibility of being protected from pre-trial imprisonment, and thus from waiting the process of going to court in local jails, has become one of the major challenges for convicted women in America. ${ }^{17}$

The fact that a large number of women are kept in local jails before the crime is determined leads to many problems for both their families and themselves. Even though they are shorter in local jails than in prisons, it is much more difficult for them to communicate with their families, the cost of making a phone call for these people is $\$ 1.50$ per minute, and these women are currently lacking financial means. When it comes to other means of communication, even sending mail and postcards in some local prisons is extremely limited, and in some, even a real letter is not allowed. Unlike the men imprisoned here, about $80 \%$ of women are mothers, who are single-parent and take responsibility for their children alone; and the main concern of mothers is the self-care and caregiver need of their children. Therefore, the children of these mothers are highly sensitive to the domino effect due to their struggle with this heavy burden, and consequently their tendency to crime may be higher. ${ }^{18}$ This situation creates additional problems for sentenced mothers and causes psychological pressure on them. Hence, the mental and psychological problems of sentenced women are much higher than that of men in correctional facilities and prisons, and their need to be backed by support and guidance activities that serve specific purposes is also greater than that of men.

Moreover, even though the proportion of all people sentenced to state and federal prisons from those held in local jails is $10 \%$, approximately one quarter of women convicted in local prisons are sent to state and federal prisons by the system. ${ }^{19}$ For this reason, it is obvious that local prisons are the source of the problems mentioned above regarding women as well as the main problems arising from both increasing numbers of prisoners and imprisonment of people whose crime is not determined yet. Thus, even if there is a

\footnotetext{
16 Aleks Kajstura, "Women's Mass Incarceration: The Whole Pie 2017", access: 13 October 2019, https://www.prisonpolicy.org/report/pie2017women.html.

17 Aleks Kajstura, "Women's Mass Incarceration: The Whole Pie 2017," (no pages).

18 Aleks Kajstura, "Women's Mass Incarceration: The Whole Pie 2017," (no pages).

19 Aleks Kajstura, "Women's Mass Incarceration: The Whole Pie 2017," (no pages).
} 
possibility to be released after staying in the local prison for female prisoners who are maybe found innocent, it is also a total problem for their families and children. The US Justice and Correctional authorities also provide women in local prisons, if necessary, with medical treatment and rehabilitation services and try to protect them from the trauma of a crime they have not yet convicted until the trial. Among those women who are sentenced to state and federal prisons after being convicted are directed to various rehabilitation and counseling services according to their needs.

\section{Profile of Imprisoned Women and Paradigm Shift}

The prevailing correctional and rehabilitation services for male criminalities and guilt in the American penal and correctional authority system has been revised in favor of the women's needs in the 2000s, in parallel with the increase in the number of female prisoners and the inequality in provided correctional services. The increasing number of prisoners against women has changed the face of the services in prisons provided by American Correctional Authorities, and required the differentiation of counseling services for both the physiological and psychological needs of female prisoners that are quite different from men. As a result, the diversification of correctional mechanisms and support services were ensured. In terms of mental complications and trauma experiences, it has become a real necessity for convicted women to be supported with additional support programs along their necessary treatments.

Regarding the economic profile of women in prison, it has been ascertained that the annual income of imprisoned women is much lower than that of sentenced men and therefore many have to wait in local jails until the court because they cannot afford their bail. According to a survey conducted on women who cannot afford the bail, their annual income is $\$ 11,071$ on average. The average annual income of black women among these women is only $\$ 9,083$, which is equivalent to $20 \%$ of the average annual income of a free white woman. Thus, when the bail amounts to an average of $\$$ 10,000 , women are obliged to wait in local jails until the court process instead of paying the bail. ${ }^{20}$

\footnotetext{
20 Aleks Kajstura, “Women's Mass Incarceration: The Whole Pie 2017," (no pages).
} 
From the viewpoint of the crime profile, the majority of women in local jails are imprisoned for non-violent crimes. According to the latest available data, $32 \%$ of these women are imprisoned for property crimes, $29 \%$ for drugs and $21 \%$ for public crimes. More than half of these women imprisoned in the judicial system struggle with unemployment and poverty. $60 \%$ of these imprisoned women do not have a full-time job before being imprisoned. And 30\% of this group gets along with economic support called public aid, this rate is less than $8 \%$ for male prisoners. ${ }^{21}$ When the relationship between financial difficulties, the crime profiles and economy has been identified, many programs, such as vocational training and enabling high school and university education for prisoners in American prisons has been launched.

Imprisoned women face physical and psychological health problems, mental disorders, post-traumatic stress disorder whereas this rate is $35 \%$ for male prisoners. $32 \%$ of the women in local prisons struggle with severe mental disorders such as major depression, $848 \mid \mathrm{db}$ bipolar disorder, and schizophrenia. ${ }^{22}$ According to the statistics of the Department of Justice, $75 \%$ of the woman in local prisons have had the symptoms of mental disorder during the last 12 months before being released. ${ }^{23}$ Almost one-third of the convicted women suffered sexual abuse or harassment during their childhood. Furthermore, $53 \%$ of these women struggle with medical problems while $82 \%$ of fight against drug and alcohol addiction. ${ }^{24}$ Moreover, $86 \%$ of the imprisoned women are exposed to sexual abuse, $77 \%$ physical violence mostly by husband, and $60 \%$ by domestic violence / caregiver abuse. Thus, they suffer from traumatic stress disorder. ${ }^{25}$ In addition to all of these, being guilty and imprisoned triggers their memory of abuse and creates an additional traumatic situation.

21 Elizabeth Swavola et al., "Women and Jails in an Era of Reform", 9-10.

22 Laura M. Maruschak, "Medical Problems of Jail Inmates", ( Bureau of Justice Statistics Special Report, 2006), access: 13 October 2018, 15, http://www.bjs.gov .

23 Doris J. James - Lauren E. Glaze, "Mental Health Problems of Prison and Jail Inmates," (Bureau of Justice Statistics Special Report, 2006), access: 1 October 2018, 15, http://www.bjs.gov. NCJ 213600.

24 Elizabeth Swavola et al., "Women and Jails in an Era of Reform", 8-15.

25 Allen J. Beck et al., "Sexual Victimization Reported by Adult Correctional Authorities 2009-11", (Bureau of Justice Statistics Special Report, 2004), access: 1 October 2018, 12, http://www.bjs.gov NCJ 243904. 
Additionally, past-trauma experiences of female criminal offenders that result in mental health complications are much higher than that of men. At the same time, they are more likely to experience sexual victimization in prisons than men. Between 2009 and 2011 , women constituting approximately $13 \%$ of the total number of prisoners were sexually victimized, $27 \%$ by convicts and $67 \%$ by staff. ${ }^{26}$ However, because of the lack of effective screening, the prison system fails to detect these traumas unless it shows an obvious symptom. ${ }^{27}$ Studies have shown that in addition to the existing trauma of female offenders, trauma situations are increasing day by day due to the negative effect of imprisonment on mental health, and these trauma stages of female prisoners tend to progress if they are not treated during the imprisonment or after their release. ${ }^{28}$ This is, by all means, attempted to be taken under control through correction, rehabilitation and treatment programs, including the US Department of Justice, federal and state prison officials, municipalities, church officials, psychologists, social service expert and volunteers. In this sense, treatment programs have been created and implemented with a specific purpose, based on a clear concept and theory, requiring a certain period, having a special structure and method, having past success / treatment that can be measured and carried out by trained personnel and specialist.

Support services offered to prisoners are designed specifically as programs that support women due to the increase in the number of women prisoners, the criminal profile and the experience of trauma being different from men, and much worse financial conditions of women than male prisoners. Support programs involving and sometimes prioritizing women prisoners have evolved from a male-dominated character to a problem-solving aspect for women.

26 Elizabeth Swavola et al., "Women and Jails in an Era of Reform", 9-10.

${ }^{27}$ Henry J. Steadman et al., "Validation of the Brief Jail Mental Health Screen," Psychiatric Services $56 / 7$ (2005) : 816- 22; Robert L. Trestman et al., "Current and Lifetime Psychiatric Illness Among Inmates Not Identified as Acutely Mentally Ill at Intake in Connecticut's Jails," Journal of the American Academy of Psychiatry and the Law 35 /4 (2007) : 495.

28 Suzanne Riley \& Holly M. Harner, "The Impact of Incarceration on Women's Mental Health: Responses from Women in a Maximum-Security Prison," Qualitative Health Research 23:1 (2013): 29. 
In this respect, in order to provide a solution to the dramatic increase in the number of female prisoners and prevent their reimprisonment, state and federal correctional authorities in the United States have begun to support imprisoned women through counseling and guidance services aiming to provide support for three different purposes: 1) before they enter the prison system, i.e., during their detention and while they are not yet convicted, 2) during the period they have entered and been sentenced to prison, 3) after being released in order to help them to accommodate within society. Within this context, parental education, especially given during conviction, has helped to build strong family relationships that reduced prisoners' tendency to commit crime again and made them psychologically stronger and healthier. ${ }^{29}$

\section{Services for Women}

\section{1) Correctional Boot Camps}

$850 \mid \mathrm{db}$ Boot camps are defined as correctional activities designed and conducted for prisoners. The main objective of the program is to discipline the prisoners, to prevent them from committing a new crime after their release, to reduce the increasing number of criminals in prisons and the costs of prison operation and correction. Designed in the late 1980s and early 1990s, boot camps were initially implemented by the State Correctional Centers as 75 camps for adults and 30 for young people. Municipalities planned 18 camps and applied them in local prisons. ${ }^{30}$

The main goal of camp programs is to discipline the lives of criminals. Assuming that the best method of discipline in this context is military, in this sense, these camps are shaped by disciplinary methods for soldiers, and are in the form of basic military training. It is implemented as a strict physical activity program in order to introduce the disciplinary methods and activities that criminals have not yet met in their lives and to enable them to apply these activities. In boot camps, prisoners are provided with drug addiction counseling and are required to practice physical activities such

\footnotetext{
29 James Boudouris, Parents in Prison: Addressing the Needs of Families (Lanham :MD American Correctional Association,1996), 35.

30 Parent, "Correctional Boot Camps", 2.
} 
as climbing, running, push-ups, and jumping from high altitudes for periods ranging from 90 to 180 days. ${ }^{31}$

Although this program aims to provide the person with selfdiscipline, self-esteem and support in accomplishing difficult tasks, it does not offer any trainings and psychological counseling services to change behavior. This missing components led to a lot of criticisms of the camps, and it was argued that the program should be enriched with additional support programs such as drug treatment and employment opportunities. ${ }^{32}$ Within the framework of these criticisms, the boot camps were revised by adding alcohol and drug addiction treatments, social communication skill trainings, as well as, intensive observation programs, electronic monitoring, house arrest and randomly urine test after being released. ${ }^{33}$

In the beginning of the 1990s, a limited number of female prisoners were admitted to these camps, which were exclusively for men. This program, which is designed especially for young male criminals and designed with an extreme masculine approach, has started to accept women with the same parameters. The introduction of boot camp programs for women is one of the most important indicators that the male-dominated structure in American prisons has started to change in favor of women. However, those who designed boot camps during this period ignored the needs and concerns of women and directly included women in the same masculine format that was designed and implemented exclusively for men. No revision has been made even regarding the solution of an ordinary women's problem. In fact, women have failed to carry out the heavy physical activities they had to do in these camps, and this has led some female prisoners to face a failure and trauma again. ${ }^{34}$

When the general implementation of the program is considered, no basic needs have been met for women, especially mothers and their children, and they have been restricted or completely

31 Doris Layton Mackenzie - Claire Souryal, "Inmates' Attitude Change during Incarceration: A Comparison of Boot Camp with Traditional Prison", Justice Quarterly 12/2 (1995) : 325-326.

32 Joycelyn M. Pollock, Counseling Women in Prison, First Printing(California: Sage Publications,1998), 123-127.

33 Parent, "Correctional Boot Camps", 2.

34 Parent, "Correctional Boot Camps", 3-4. 
prohibited from visiting during the camps in order to discipline the prisoners. In addition, it was found that no training program for parenting was provided, and that women who suffered much higher rates of physical and sexual violence than male prisoners were not supported. Moreover, different treatment and counseling services were not offered to men and women who had different experiences of alcohol and drug use, and women had to participate in programs designed and implemented only for men. Furthermore, these camps are implemented differently in each state and there is no program unity. In some states such as New York and Louisiana, treatment, counseling, training and rehabilitation services are attached more importance to, while in states such as Georgia and Texas, these activities are much less involved. ${ }^{35}$

While being criticized that disciplining women by doing "pushups" ignores gender differences in the society, and that intense physical activity and military drills in practice were not suitable for women, those responsible for the program and the official correctional authorities continued to express that these camps were extremely helpful in the disciplining of prisoners and prisons. Nevertheless, nationwide boot camps have been found to be slightly successful in reducing the rate of re-offending of female prisoners. ${ }^{36}$ According to some researches, more than half of the female prisoners were re-arrested within the first three years after being released and $40 \%$ of them were sent back to prison. When the crime profiles of these women are examined, it is identified that $65 \%$ of them go back to prison for the same crime. ${ }^{37}$ However, although there is no official record of re-offending rates of female prisoners attending boot camp training, a partial improvement has been found. ${ }^{38}$

According to another study conducted on the impact of these camps on prisoners, it was observed that there were positive changes in attitudes and behaviors of those who joined camps, albeit in the short term, and that they acquired problem solving skills. However, it was seen that these positive changes did not reduce the

35 Mackenzie - Souryal, "Inmates' Attitude Change during Incarceration: A Comparison of Boot Camp with Traditional Prison", 326.

36 Pollock, Counseling Women in Prison, 123-127.

37 Merry Morash - Hoan N. Bui, "The Impact of Network Relationships, Prison Experiences, and Internal Transformation on Women's Success after Prison Release" Journal of Offender Rehabilitation 49/1, ( December 2009): 2-3.

38 Pollock, Counseling Women in Prison, 125. 
re-committing a crime of the offenders at the intended and expected rates after their release, thus providing a very low benefit, whereas in the partially revised camps under the criticism they received, more treatment services and intensive monitoring activities were carried out after the release but due to heavy physical activities and strict disciplinary characteristics, it did not achieve the aimed success. ${ }^{39}$ There was a relatively small decrease in the number of criminals and correctional costs. ${ }^{40}$ When the aimed success was not achieved, almost one third of these camps were closed, and only 51 camps continued their activities. The average daily population of state camps has also diminished by more than $30 \%{ }^{41}$

In conclusion, the program is highly meaningful in that it provides an intensive program ranging from 90 to 180 days to the prisoners as soon as they enter the prison. Because even if a person is guilty, he or she is always open to education and also to transformation. From the moment he or she enters the prison, trying to discipline the person and implementing a formal program to ensure such a discipline can be considered a success in the name of prison administration and management. The aimed success could not be achieved with its current form, but it was a significant step in identifying failures, revising it as necessary and initiating new projects.

\section{2) Family Therapies}

According to a study about prisoners and their families, maintaining a healthy family-child relationship in prison also reduced the rates of re-imprisonment, particularly conditional release violations, and contributed to the success of life after release. ${ }^{42}$ Therefore, woman-oriented parenting programs such as "Family Therapies", "Systematic Training for Effective Parenting", "Mothers Inside Loving Kids", "Alternatives to Incarceration", "Mothers and Their Children", "Girls Scouts Behind Bars", "Mother-Baby Programs" are organized in American prisons to help prisoners overcome their problems. The main objective of these programs that are applied to

\footnotetext{
Pollock, Counseling Women in Prison, 124-126.

Pollock, Counseling Women in Prison, 126.

1 Parent, "Correctional Boot Camps", 2-3.

42 Creasie Finney Hairston, "Prisoners and Their Families: Parenting Issues During Incarceration", Prisoners Once Removed: The Impact of Incarceration and Reentry on Children, Families and Communities, eds. J. Travis - M. Waul (Washington, D.C.: The Urban Inst. Press, 2003), 261-262.
} 
female criminals is to protect and strengthen the mental health of women while they are in prison or return to their children and families after being released, and to prevent them from repeating a crime. $^{43}$

Family therapies offered in prisons support the prisoners in resolving conflicts with their family. These therapies also supports them by focusing on internal dynamics leading to physical abuse, inter-siblings violence, child abuse and neglect, drug and alcohol addiction, combating unemployment and economic problems, dependence, child rearing, establishing a qualified family relationship, the ability to adapt to rapid change outside, coping with emotional loss and social isolation resulting from death or separation. ${ }^{44}$

As the basis of family therapy in prisons, family members are not treated separately, but rather the family and its problem are considered as a unit in itself. Therefore, those who apply therapy in prisons aim to heal with the families of prisoners who struggle with many psychological problems such as suicidal tendency, autism, schizophrenia or with addiction problems. According to the principles of family therapy, each family has to achieve a balance and strive for it. Changes in an individual within the family will result with a total change of the family considered as a unit alone. For this reason, a woman prisoner who has to deal with her current problem is actually a woman who has already been neglected and abused by her family. It is hereby very significant to take this therapy together with the family and to help the family develop the right approach and to prevent them from experiencing similar problems again. ${ }^{45}$

While dealing with these problems in the prison, basic principles and practices of family therapy are taken into consideration. Role playing, communication and intimacy are taken to the center to rehabilitate the prisoners with their families, while at the same time, they try to repair the trauma caused by any member of the family and not from the prisoner. In addition, the prisoner's family gains awareness of the sensitivity of the prisoner's situation in these

43 Pollock, Counseling Women in Prison, 116.

44 Patricia Van Voorhis et al., Correctional Counselling and Rehabilitation, (Cincinnati, OH: Anderson, 1992), 174.

45 Pollock, Counseling Women in Prison, 115. 
therapies, which is important for the prisoner to establish strong family ties.

The biggest handicap of family therapies offered in American prisons is the low participation of families with poor economic conditions due to the arrival and leaving costs of the program. Another handicap is the psychological and social difficulties faced by the drug-addicted prisoner, who are alienated from the family due to the trauma caused by the prisoner, to re-establish this relationship. Apart from these two difficulties, any negative aspect of the family therapies offered in prison couldn't be detected and, unlike, it was highly successful.

\section{3) STEP- Systematic Training for Effective Parenting}

Another special program for imprisoned women is the support program called Systematic Training for Effective Parenting (STEP). With training programs ranging from 4 to 20 weeks, women prisoners receive training on communication skills, self-confidence, parenting skills, stages of child development, recognizing their feelings, expressing correctly and directing them when necessary. The aim of this training is to improve the injured bonds of mother and child, to increase the opportunity of family reunification, to reduce the possibility of intergenerational crime, and to support and strengthen mothers to become better parents. ${ }^{46}$

Most of the time, these trainings are carried out by volunteers and do not require any cost. Some prisoners who have achieved success at the end of the training and who have made progress are given the privilege of meeting with their children in addition to regular visits, however, no special meeting areas have been designed for mother and child, and the mother meets her child in the regular meeting room. Women participate in these programs with great enthusiasm and express their demands in the needs assessment questionnaires, most of the time, the classes are full and there is a high level of success due to the possibility of gaining additional visits. $^{47}$

46 Pollock, Counseling Women in Prison, 110-111.

47 Mary Jeanette Clement, "Parenting in Prison: A National Survey of Programs for Incarcerated Women," Journal of Offender Rehabilitation 19/1-2 (1993), 89-100. 


\section{4) MILK- Mothers Inside Loving Kids}

In the 1990s, $56 \%$ of women in federal prisons and $65 \%$ of women in state prisons had at least one child. According to the latest census in US state and federal prisons, in 2007, 65,600 mothers were sentenced, leaving 147,400 children behind. And in 2010, mothers of nearly 300,000 children were sentenced. As the report published in August 2008, either the mother or the father of 1.7 million children under the age of 18 have been sentenced, which corresponds to $2.3 \%$ of the entire child population in the United States. While there were 881,500 children whose father was convicted in 1991, in 2007 this was more than 1.5 million and increased by $77 \%$. Likewise, the number of children whose mothers were convicted raised from 63,900 in 1991 to 147,400 in 2007 and increased by $131 \% .^{48}$

These children had to deal with many problems such as antisocial disorder, mental health problems, academic failure and economic deficiency due to the dominant effect of having a convicted parent. More than half of the mothers in federal and state prisons cannot see their children, and those who can see meet them not in child-friendly areas and without establishing a physical bond. ${ }^{49}$ Mothers are not allowed to touch and hug their children even when they leave them. Another problem is that children are subjected to strict searches and disciplinary prison rules. Such mother and child meetings do more harm than good. Because of 1) the abovementioned striking rates of the number of children of the sentenced mothers 2) and the problems of the above-mentioned general visit prohibitions applied to children and mothers, 3) the weakening or dissolution of the mother-child bond due to these problems 4) and the need of ensuring that the mother and child spend qualified time, the US Department of Justice and Correctional Authorities have tried to find a solution, and thus the MILK program has been designed and implemented for both sentenced mothers and their children.

48 Lauren E. Glaze - Laura M. Maruschak, "Bureau of Justice Statistics Special Report: Parents in Prison and Their Minor Children", (Bureau of Justice Statistics Special Report, 2008), http://www.bjs.gov NCJ 222984.

49 Chesa Boudin et al.,"Prison Visitation Policies: A Fifty State Survey," access: 15 November 2018, http://ssrn.com/abstract=2171412 ; Julie Poehlmann et al., "Children's Contact with Their Incarcerated Parents: Research Findings and Recommendations", American Psychologist 65/6 (2010): 576-577. 
The main objective of the "Mothers Inside Loving Kids (MILK)" program, which was first implemented in Virginia and Fluvanna Correctional Centers, is to develop a healthy mother-child relationship. In the program, which is also supported by volunteers, the prevention of child neglect and abuse and the motivation of the family in this respect plays an important role. The MILK program is based on three components: child-friendly visits, family education including the convicted mother and those concerned with the care of the child outside, and voluntary group support. ${ }^{50}$ The MILK program organizes orientation programs about visits for mothers and children before they meet in prison, in addition to this, mothers get child development and family education programs, as well as, courses for gaining the ability to live independently. In addition to these lessons, education is given to the caregiver or family elders who accompany the child of the mother in prison. ${ }^{51}$

Within the scope of this program, mothers and children are given additional right to visit in a child-friendly area designed in prison, so that the child can spend a special time with his / her mother, establish a one-to-one relationship and, in contrast to normal visitation areas, allow the mother and child to establish physical bonds. Unlike the Systematic Training for Effective Parenting, in this program, it is a great privilege to have child-friendly spaces for visitations that has been an important factor in the success of the program. Even if the child and the mother are in prison, they may come together in private areas for a while, make physical contact and embrace each other. Besides, mothers who participate in this program have the right to communicate more with their children by telephone, e-mail or letter. ${ }^{52}$

The trainings given the imprisoned mother and the person taking care of the child outside together, aim to establish a stronger connection between them and to develop harmony and healthy communication between the family and the caregiver. During this training, the executives of the MILK program have the opportunity to observe the caregiver's approach to the child and to direct the caregiver, if required. In more severe cases where it may be insuffi-

50 Elizabeth Coleman, Mothers Inside Loving Kids: An Evaluation Of A Parenting Support Program For Inmate Mothers (PhD Thesis, University of Virginia, 2017), 55-57.

51 Clement, "Parenting in Prison", 89-100.

52 Coleman, "Mothers Inside Loving Kids", 106-111. 
cient to direct the caregiver, they have the chance to direct the family about the caregiver. Thus, the person taking care of the child gains awareness of the difference between caring for the child of a sentenced mother and caring for the child of a mother who has to go to work in an ordinary family, and it is aimed to develop an attitude accordingly. In the United States, some children of imprisoned parents are placed in preventive care, and it doesn't have always positive consequences for children, as this is something that cuts off ties and relationships with their school, friends, siblings and other family member. According to a study conducted in 2008, $80 \%$ of children whose fathers are convicted are cared for by their own mothers, while only $37 \%$ of children whose mothers are convicted are cared for by their own father, $42 \%$ by family elder, and $23 \%$ by other relatives or the child is protected by the state. ${ }^{53}$

The MILK program is constructed both to help children of imprisoned mothers holding on life and to rehabilitate mothers. It is reported that mothers who take part in this program have devel$858 \mid \mathrm{db}$ oped more positive behavior and were much more successful in acquiring self-esteem than those who did not participate. ${ }^{54}$

\section{5) MATCH- Mothers and Their Children}

This program is a training service given to prisoners by professional staff and volunteers regarding issues such domestic violence, prevention of drug use, child development, the ability to be a parent, health and hygiene. The program, which is also open to mothers who have been sentenced and released, helps these women find employment, networking and counseling on parental issues in their re-started lives after conviction.

This program, implemented in California, was planned for local prisons and was not implemented in state and federal prisons. In a specific part of local prisons, imprisoned mothers and children are brought together every weekend, however, in order to be entitled to this opportunity, sentenced mothers must have attended parental education programs on weekdays. ${ }^{55}$ It can be said that the program is well designed, as it is open to ex-prisoners who were released, as well as the fact that the opportunity for imprisoned mothers to

53 Coleman, "Mothers Inside Loving Kids", 19-20.

54 Coleman, "Mothers Inside Loving Kids", 76-80.

55 Pollock, Counseling Women in Prison, 112. 
spend some time with their children is provided on the condition mothers attending the parental programs. Furthermore, it is obvious that the program executives, who support women in finding jobs and networking, did not ignore the crucial economic problems of female prisoners and tried to provide solutions for them. In all these aspects, it is possible to say that it is a comprehensive program that aims to support both the ex-convicts and the already sentenced mothers and their children.

\section{6) Girls Scouts Behind Bars}

The main feature of this program, which includes trainings about prevention of violence drug use, prevention of early pregnancy, and gaining self-esteem, is directed at sentenced mothers and their potentially threatened daughters. The program, which was implemented in 1992 by The National Institute of Justice and Girl Scouts of Central Maryland, served thousands of young girls and sentenced mothers throughout the country. ${ }^{56}$ The program, which is implemented by correctional facility administrations, Girl Scouts staff and volunteers, especially in Maryland, Florida, Ohio and Arizona, allows imprisoned women to meet their girls aged between 5 and 17 in two Saturdays of each month. Two hours of group projects and structured play activities take place between the mother and her daughters. This program is more of an educational activity than a meeting. In this sense, the program offers enhanced relationship for sentenced mothers and daughters. On another Saturday, the girls participating in this program meet volunteers at a specific location in the city and spend time together as a team and perform various activities. The sentenced mother and the person taking care of the child cannot take part at this event outside.

This program, funded nationally by the U.S Department of Justice's Office of Juvenile Justice and Delinquency Prevention since 2003 , covered the transportation costs of the girls who cannot visit their mothers in prison because they are living hundreds of miles away from the prison where her sentenced mother was imprisoned, and have financial difficulties. ${ }^{57}$

\footnotetext{
56 Fiona Soltes, Girls Scouts Beyond Bars Providing a Better Path, (New York: Office of Juvenile Justice and Deliquency Prevention, 2012), 5.

57 Pollock, Counseling Women in Prison,112; Soltes, Girls Scouts Beyond Bars, 5.
} 
Therefore, it was taken into consideration that, because of their mothers, they had started much earlier or experienced much more than their peers in terms of drug use, anxiety, depression and physical aggression. In this context, it has been implemented with the aim of maintaining the mother-daughter relationship in a healthy way through regular visits to ensure that these children are more susceptible to the above-mentioned domino effect and that these children are not part of the cycle of crime by following their mothers. ${ }^{58}$

The main weakness of the program is the lack of general counseling and individual counseling. Besides, very less parenting education is given to the mothers in the program. Only in Florida, mothers receive regular parental education support from psychologists. This is inevitable because of the limited hours of the program. Although the duration of time is short, and individual counseling and parenting trainings are limited, the satisfaction of mothers and daughters participating in the program is quite high. As in the $860 \mid \mathrm{db}$ MATCH program, the missing aspect of the program can be completed by requiring mothers to participate in other parenting trainings during the week in order to participate in this program. ${ }^{59} \mathrm{An}$ other criticism directed to this program is the exclusion of the sons of sentenced mothers.

\section{7) Celebrating Camps}

In the camp, which was first implemented in 1988, restaurants, tents and bathrooms were set up for imprisoned mothers and their children within the prison facilities, and mothers were allowed to camp with their children every weekend during the summer months. The program, from Friday afternoon until Sunday afternoon, gave mothers and their children an opportunity to play structured games and to set a campfire, and also allowed mothers to spend time with their children without involving any other activity. ${ }^{60}$

58 Soltes, Girls Scouts Beyond Bars, 5.

59 Marilyn C. Moses, "Keeping Incarcerated Mothers and Their Daughters Together: Girl Scouts Beyond Bars" (National Institute of Justice: Program Focus, 1995), 3-10.

60 Norma J. Stumbo- Sandra Little, "Campgrounds Offer Relaxed Setting For Children's Visitation Program" Corrections Today, (August,1991):138. 
During these camps, no obvious security personnel has been assigned in order to create a mother-child friendly environment, only social workers who organized and carried out activities at the institution have been accompanied parents and children. ${ }^{61}$ The program, which was first implemented in the Illinois Correctional Facility and yielded positive results, has been applied in other prisons and gave positive outcomes each time. The budget of the program was funded by the donation of federal government and after the end of the donation, the program had to be supported by the prison budget in order to ensure the permanence and the sustainability of the program. In this context, the program was carried out with the prison budget. ${ }^{62}$ Like the other programs mentioned above it provides additional and extended visits, therefore, sentenced mothers and their children show great interest in this program and it became successful.

\section{8) ADAPT-Alcohol and Drug Abuse Prenatal Treatment Pro- gram}

$\mathrm{db} \mid 861$

This program, which provides alcohol and drug treatment to pregnant prisoners, serves jointly with the health departments of the correctional facilities and municipalities. In this program women receive trainings of prenatal care and treatment, alcohol and drug addiction and their treatment, child care, women's health and hygiene. In addition, weekly sessions about problem solving and parenting workshops are organized to allow mothers to express their problems easily. They are also provided with training and support in raising their living standards.

In the study conducted to evaluate this program, it was determined that drug and alcohol test results of pregnant mothers whose due date of their birth is close were extremely low. It was also noted that the birth weight and height of the babies of the pregnant mothers who participated in the program were much better than those of the mothers who did not participate..$^{63}$ It is therefore clear that the program is successful in achieving its objectives, thus,

61 Stumbo - Little, “Campgrounds Offer Relaxed Setting For Children's Visitation Program", 136.

62 Pollock, Counseling Women in Prison, 112.

63 Pollock, Counseling Women in Prison, 116. 
providing such a service, even if for expectant mothers who are convicted, is a responsibility that should not be neglected by concerned authorities.

\section{9) Education Completion Programs}

It is extremely important to direct prisoners to educational and vocational activities that are recorded by officially validated documents in order to reduce the rates of re-imprisonment, to ensure positive management in prison and to ensure long-term transformation after release. In order to achieve these goals, American penal and correctional authorities provide prisoners the opportunity to attend training and certificate programs to obtain a high school diplomas according to their current level of education, and to take vocational training courses and even to receive university education for those who have completed prerequisites. In this context, university education in prison not only helps to create a positive environment and network and to reduce the negativity of the prison environment, but also contributes to the rehabilitation and socialization processes and the restoration of damaged family relations. According to a study by The Bedford Hills College Program, the education completion programs have a very positive effect on the children whose mothers are convicted. It is stated that the children are proud of their mothers' academic achievements; and these mothers are now becoming good role models for their children, who are inspired by their successful mothers. ${ }^{64}$ These programs provide the prisoners with an educational background that they never had, as well as the possibility of becoming better parents and therefore, the chance to cling to life and make a new start after being released.

According to the study of the New York State Correctional Department, providing university education in prison is less than the cost of re-offenders to prison. ${ }^{65}$ According to the Bureau of Justice Statistics, the average annual operating cost per prisoner in 2001

64 Wendy Erisman - Jeanne Bayer Contardo, "Learning to Reduce Recidivism: A 50-State Analysis of Postsecondary Correctinal Education Policy, National Institute for Higher Education Policy,( November 2005): 27-37.

65 Michelle Fine et al., "Changing Minds The Impact Of College In A Maximum-Security Prison: Effects On Women in Prison, The Prison Environment, Reincarceration Rates And Post-Release Outcomes" (NewYork :The Graduate Center of the City University of New York \& Women in Prison at the Bedford Hills Correctional Facility, 2001), 4-7. 
was $\$ 22,650 .{ }^{66}$ The average annual cost per student at a standard state university such as The State University of New York (SUNY) is less than $\$ 8,000 .{ }^{67}$

Therefore, allowing prisoners to complete an education program during their first detention is far more beneficial for the country's material and moral well-being. Studies about reducing recidivism after release have proved that the most effective way to prevent re-arrestment is to offer prisoners the opportunity to receive or complete training. Considering the statistics in New York State alone, in 1998, 27.993 men and women left prison after completing their sentences, but $43.8 \%$ of them were re-arrested the same year. According to the IHEP (Institute for Higher Education Policy) survey in 2005, it has been noted that the rates of re-offending and detention of those who have completed training programs reduced significantly and that those who have received a diploma get less public aid. ${ }^{68}$ As a result, the prisoner, trying to survive by receiving public aid, is now accepted by the society and the state as a respected person who can pay taxes, and chooses to continue this respectable life as a better citizen than to commit crimes again.

The most well-known and prominent one of the education completion programs is the education completion program of Boston University Prison Training Program, founded by activist Elizabeth Barker in the 1970s. In 1972, the University of Boston, which granted the first course credit to the prison education program, provided this education support in Framingham Massachusetts in 1991 only to women. By the end of the 1980s and early 90s, many universities in Massachusetts began to give classes and courses in prison.

Despite many benefits mentioned above, in 1994, under the law on the prevention of violent crimes signed by President Bill Clinton, over 350 prisons were suspended around the debates that criminals don't deserve education, and prisoners were denied access to this education funded by Pell Donations. Due to the lack of funding, universities withdrew from these activities in prisons, but

\footnotetext{
66 James Stephan, "State Prison Expenditures 2001"(Bureau of Justice Statistics, 2004),1, http://www.bjs.gov, NCJ 202949.

67 Stephan, "State Prison Expenditures 2001", 1-9.

68 Erisman - Contardo, "Learning to Reduce Recidivism,2 27-37.
} 
Boston University has continued to serve since 1998, focusing solely on undergraduate courses rather than graduate courses. In October 2016, 185 students received bachelor's, 39 master's, 23 both bachelor's and master's degrees, in this sense, the education completion programs has achieved success. These programs continue in many prisons in the United States and are successful.

\section{Conclusion}

After the determination of the fact that the rapid increase in the number of the female prisoners and their problems are not just related to inmates, but also include the families, it has enabled a change to reduce the number of imprisoned women in the United States and to highlight the needs of women and produce solutions to these needs. Within this framework, many programs and projects, some of which also mentioned in this paper, have been implemented in prisons, which give spiritual support to prisoners and make them stronger, provide services to strengthen their family relations and grant additional visitation rights. In this way, it has been possible to re-evaluate and strengthen the relations of the prisoners with their families, especially with respect to sentenced mothers and children. From this point of view, positive results have been obtained regarding the reintegration and adjustment of female prisoners.

The United States, within this context, showed its achievements in supporting and guiding prisoners rather than in reducing crime and criminals. The new approach and studies within this framework have resulted in much more productive outcomes in order to perceive criminals as individuals who are candidates for recovery rather than being seen as those who have been lost and losers in the society. Supporting a prisoner physically and psychologically especially from the moment he or she enters the prison system, and directing him with the necessary medical treatment, rehabilitation and guidance activities, parenting programs, and making him or her a part of the society and successful again, are fundamental issues for achieving a healthy and solid social structure. In this respect, opportunities for taking or completing education, efforts to maintain and strengthen family ties, financially and morally support the prisoner mothers, and designing programs and projects to support the family members whom the prisoner left behind, especially their children, are not rewards for the criminals but 
contributions to society itself. The reintegration of a convicted mother is essentially a reintegration of a family in a healthy and respectful way, and therefore, the institutions in the country, in cooperation, should pay attention to provide counseling and spiritual support activities for sentenced mothers involving their families. In this context, it is obvious that the revision -based on the needs- and dissemination of the programs with positive results, some of which we have included in this work, will be beneficial.

\section{BIBLIOGRAPHY}

Beck, Allen J. - Rantala, Ramona R. - Rexroat, Jessica. "Sexual Victimization Reported by Adult Correctional Authorities 2009-11". Bureau of Justice Statistics, 2004. http://www.bjs.gov NCJ 243904.

Belknap, Joanne. The Invisible Woman: Gender Crime, and Justice. Belmont, CA: Wadsworth 2001.

Bloom, Barbara - Owen, Barbara - Covington, Stephanie. Gender-Responsive Strategies: Research, Practice, And Guiding Principles For Women Offenders. Washington, DC: National Institute of Corrections, 2003.

Bronson, Jennifer - Carson, Ann. "Prisoners in 2007". Bureau of Justice Statistics, 2019. http://www.bjs.gov NCJ 252156.

Boudin, Chesa - Stutz, Trevor -Littman, Aaron. "Prison Visitation Policies: A Fifty State Survey" . Access: 15 November 2018. http://ssrn.com/abstract=2171412.

Boudouris, James. Parents in Prison: Addressing the Needs of Families. Lanham :MD American Correctional Association, 1996.

Clement, Mary Jeanette. "Parenting in Prison: A National Survey of Programs for Incarcerated

Women". Journal of Offender Rehabilitation 19/1-2 (1993): 89-100.

Coleman, Elizabeth. Mothers Inside Loving Kids: An Evaluation Of A Parenting Support Program For Inmate Mothers, unpublished PhD thesis, University of Virginia, 2017.

Covington, Stephanie S. "Women in Prison Approaches in the Treatment of Our Most Invisible

Population". Women and Therapy Journal 21/1 (1998): 141-155.

Dart, Tom ."To End Mass Incarceration, Think Local". The Wall Street Journal, May 30. Access: 9 August 2018. http://www.wsj.com/articles/ to-end-massincarceration-think-local- 1464642713.

Erisman, Wendy - Contardo, Jeanne Bayer. "Learning to Reduce Recidivism: A 50-State Analysis of Postsecondary Correctinal Education Policy". National Institute for Higher Education Policy ( November 2005): 27-37.

Faris, Jeralyn - Miller, Joann. "Family Matters: Perceptions of Fairness Among Incarcerated

Women". Prison Journal 90/ 2 (2010):139-160

Fine, Michelle - Torre, Maria Elena - Boudin, Kathy - Bowen, Iris - Clark, Judith -Hylton, Donna - Martinez, Migdalia - Roberts, Rosemarie A. - Smart, Pamela - Upegui, Debora. Changing Minds The Impact Of College In A Maximum-Security Prison: Effects On Women in Prison, The Prison Environment, Reincarceration Rates And Post-Release Outcomes. NewYork: The Graduate Center of the City University of New York \& Women in Prison at the Bedford Hills Correctional Facility, 2001. 
Glaze, Lauren E. - Maruschak, Laura M. "Bureau of Justice Statistics Special Report: Parents in

Prison and Their Minor Children". Bureau of Justice Statistics , 2008. http://www.bjs.gov NCJ 222984.

Hairston, Creasie Finney. "Prisoners and Their Families: Parenting Issues During Incarceration". Prisoners Once Removed: The Impact of Incarceration and Reentry on Children, Families and Communities. Ed. J. Travis - M. Waul. 260-282. Washington, D.C.: The Urban Inst. Press, 2003.

Harris, Alma. Building Upon The Razor Wire Women's Program By Incorporating Experiential Therapy Interventions To Treat Addictions In Women In Prison. Ann Arbor : ProQuest LLC, 2016.

Houser, Kimberly - Belenko, Steven. "Disciplinary Response to Misconduct Among Female

Prison Inmates with Mental Illness, Substance Use Disorders, and Co-Occurring Disorders".

Psychiatric Rehabilitation Journal 38/1 (2015): 24-34.

James, Doris J. - Glaze, Lauren E. "Mental Health Problems of Prison and Jail Inmates". Bureau of

Justice Statistics Special Report, 2006. http://www.bjs.gov. NCJ 213600.

Kajstura, Aleks. "Women's Mass Incarceration: The Whole Pie 2017". Access:10.09.2018, https://prisonpolicy.org/report/pie2017women.html.

Keaveny, Mary E. - Zauszniewski, Jaclene A. "Life Events And Psychological Well-Being In

866 d db Women Sentenced To Prison". Issues in Mental Health Nursing 20/1 (1999): 73-89.

Loper, Ann Booker. "Adjustment Of Prison Of Women Convicted Of Possession, Trafficking, And Nondrug Offenses". The Journal of Drug Issues 32 (2002): 22-26.

Mackenzie, Doris Layton - Souryal, Claire. "Inmates' Attitude Change during Incarceration: A Comparison of Boot Camp with Traditional Prison". Justice Quarterly 12/2 (June 1995): 325-354.

Maruschak, Laura M. "Medical Problems of Jail Inmates". Bureau of Justice Statistics Special Report, 2006. http://www.bjs.gov NCJ 210696.

Minton, Todd D. - Zeng, Zhen. "Jail Inmates in 2015. U.S. Department of Justice Office of Justice Programs". Bureau of Justice Statistics, 2018. http://www.bjs.gov NCJ 250394.

Morash, Merry - Bui, Hoan N. "The Impact of Network Relationships, Prison Experiences, and Internal Transformation on Women's Success after Prison Release". Journal of Offender Rehabilitation 49/1, ( December 2009) : 1-22.

Morash, Merry - Haarr, Robin - Rucker, Lila. "A Comparison Of Programming For Women And Men In U.S. Prisons Since The 1980s". Crime and Delinquency 40/2 (1994):197-221.

Moses, Marilyn C. "Keeping incarcerated Mothers and Their Daughters Together: Girl Scouts Beyond Bars". National Institute of Justice: Program Focus (1995): 3-10.

Parent, Dale G."Correctional Boot Camps: Lessons From a Decade of Research". National Institute of Justice, 2018. http://www.ojp.usdoj.gov/nij .

Poehlmann, Julie - Dallaire, Danielle - Loper Ann Booker - Shear, Leslie D. "Children's Contact with Their Incarcerated Parents: Research Findings and Recommendations". American Psychologist 65/6 (2010): 575-598.

Pollock-Byrne, Joycelyn M. - Edna, Erez -Laster, Kathy. "Women, Prison, and Crime," The Journal of Criminal Law and Criminology 82/ 4 (1992):1190-1194.

Pollock, Joycelyn M. Counseling Women in Prison. California: Sage Publications,1998. 
Riley, Suzanne - Harner, Holly M. “The Impact of Incarceration on Women's Mental Health: Responses from Women in a Maximum-Security Prison". Qualitative Health Research 23/1 (2013): 26-42.

Sawyer, Wendy - Wagner, Peter. "Mass Incarceration: The Whole Pie 2019”. Prison Policy Initiative. Access: 13 October 2019.

https://www.prisonpolicy.org/reports/pie2019.html.

Steadman, Henry J. - Scott, Jack E. - Osher, Fred - Agnese, Tara K. - Robbins, Pamela C. "Validation of the Brief Jail Mental Health Screen". Psychiatric Services $56 / 7$ (2005): 816-822.

Stephan, James. "State Prison Expenditures 2001". Bureau of Justice Statistics, 2004. http://www.bjs.gov.

Stumbo, Norma J. \&Little, Sandra. "Campgrounds Offer Relaxed Setting For Children's Visitation Program". Corrections Today (1991, August): 136-144.

Soltes, Fiona. "Girls Scouts Beyond Bars Providing a Better Path". Office of Juvenile Justice and Deliquency Prevention (2012):1-15.

Swavola, Elizabeth - Riley, Kristi - Subramanian Ram. Overlooked: Women and Jails in an Era of Reform. New York: Vera Institute of Justice 6, 2016.

Trestman, Robert L. - Ford, Julian - Zhang, Wanli - Wiesbrock, Valerie. "Current and Lifetime Psychiatric Illness Among Inmates Not Identified as Acutely Mentally Ill at Intake in Connecticut's Jails". Journal of the American Academy of Psychiatry and the Law 35 /4 (2007): 490-500.

United States Census Bureau. Access: 13 October 2019, http:// www.census.gov.

Van Voorhis, Patricia - Braswell, Michael - Lester, David. Correctional Counselling and Rehabilitation. Cincinnati, OH: Anderson, 1992.

Zust, Barbara L. "Partner Violence, Depression, and Recidivism: The Case of Incarcerated

Women and Why We Need Programs Designed for Them". Issues in Mental Health Nursing 30/4 (2009): 246-251. 


\section{Counseling and Guidance Programs For Women Within the Context of Paradigm Shift in US Prison Services}

Hatice KOÇ KANCA *

\section{Extended Abstract}

Based on the data supplied by both the State and Federal Correctional Authorities of the United States and Bureau of Justice Statistics, the USA has the largest population in terms of the number of criminals, and among these criminals, relatively speaking, women constitute the fastest increasing number. According to the official records of the Bureau of Justice Statistics, till the end of December 31, 2016, there were a total of $1,506,757$ prisoners under the jurisdiction of the State and Federal Correctional Authorities of the United States. Of this number, 1,395,141 were male and 111,616 were female prisoners. This would mean that the female group constituted $7.4 \%$ of the total population of prisoners. According to these statistics, even in the year 2016, which had the lowest number of prisoners, it has been officially determined that, regardless of their ages, 450 out of every 100,000 people living in the USA were convicted, and that if we consider the age of 18 and over, then 582 out of every 100,000 appear to have been imprisoned. When we look at the figures in terms of women, it is seen that 33 out of every 100.000 people living in America are female prisoners and 68 out of every 100.000 women are female prisoners. In addition, the number of the prisoners in local penitentiaries of the U.S. has increased almost five times over the past 40 years. In these places, about 157,000 people were held in 1970; almost 745,000 people were kept in 2014 . And at the end of 2017, the number was 741,000 in total, according to the statistical account published in 2018.

While there were only 12,000 women prisoners across the country in the early 80 s, over the last 40 years the number of the female prisoners has exceeded even that of the male ones, and especially since 1979, the number of women in local prisons has increased 14 times nationwide. Although prior to this date the female inmates had constituted a very small portion of the total number of prisoners, from the 1980s onwards, this small percentage began to exceed gradually as compared to the male prisoners. Moreover, almost $80 \%$ of female prisoners, unlike male prisoners, have undertaken the responsibility of their children, which has eventually resulted in the increase of the numbers of mother prisoners, and which has in turn caused the emergence of other social problems. Towards the 2000s, in the anticipation that there will be a solution to the social problems that occur inside and outside the prison, the rehabilitation services that had been previously offered to male prisoners have been revised and tailored in

Dr., Georgetown University, Department of Theology, Visiting Scholar, hk766@georgetown.edu, Orcid Id: https://orcid.org/0000-0002-8322-6667 
accordance with the needs of female prisoners. In other words, the increase in the number of the female prisoners has demanded the improvement of such services in favor of women. The lack of equality that existed between the rehabilitative services offered to the male prisoners and those offered to the female ones has paved the way for the raise of awareness towards female prisoners among the Criminal and Correctional authorities.

The American criminal and correctional authorities have designed and implemented programs aiming rehabilitation of male prisoners alone, for many years, neglecting women prisoners and the correctional works for their problems. However, due to the increasing number of female prisoners in United States prisons, the state and federal correctional authorities have faced the fact that they focus on women-oriented problems and their solution. The awareness that has emerged over time has opened the door to the paradigm shift of American correctional authorities towards women. This awareness has led to the initiation of family protection programs in some states to address the needs of women prisoners and their families more respectfully. Moreover, it has led to the launch of several new programs: inmate mothers should be included in educational programs in order to respond to the physical, emotional and psychological needs of their children; those mothers should meet with their minor children and adolescents with games and various activities in special and child-friendly rooms outside the normal visiting room; it should be given additional visitation rights for those mothers who participate in parenting trainings; a new mother should be allowed to live with her infant in a private section for up to 18 months. In this article, parallel to this paradigm shift especially in the late 90s and early 2000s, some national and local correctional works and projects focused on the needs of female prisoners that was initially neglected but then taken into consideration due to the increasing number of women convicts and needs peculiar to them, will be examined. The treatments, medical processes, physical and mental treatment methods required by the clinical psychology offered to the prisoners based on prisoners' needs are out of our scope. This study, rather, focuses on practices -their effects and efficiencycarried on successfully with combined efforts of criminal correctional authorities, psychologists, municipal and church officials, social service experts and volunteers that aim to support female prisoners, especially those with children.

Keywords: Incarcerated women, Parenting preservation program, Extended prison visitation, Correctional programs.

\section{箱}

